\title{
ISLAMISASI PRINSIP COUNTER ACCOUNTING
}

\author{
Dayno Utama \\ Lembaga Ilmu Pengetahuan Indonesia, Indonesia \\ E-mail: dayno.utama.sn@lipi.go.id
}

\begin{abstract}
The purpose of this study is to explore the idea of Islamization of counter accounting principles. Such an Islamization is necessary because counter accounting principles are formulated by using the philosophy of punk from the western society which has different beliefs. In addition, the idea of Islamization in this study shows that Islamic knowledge can indeed be developed continuously. Therefore, the claim that there is no development inside this knowledge, and that it cannot be categorized as science, will no longer exist. This study reveals the findings that the wisdom from argumentation which constructs the principles of counter accounting is parallel with the wisdom from Islamic values as interpreted by experts of Islamic accounting. The Islamization of counter accounting principles confirms the truth of belief in the existence of Allah and His revelation.
\end{abstract}

Keywords: Islamization, Islamic values; counter accounting principles.

\section{Pendahuluan}

Dalam salah satu upaya perumusan prinsip counter accounting (akuntansi perlawanan) terdapat pemanfaatan nilai-nilai Islam untuk memperkuat salah satu rumusan prinsip counter accounting, yaitu prinsip kreativitas tanpa batas dalam berbagai keterbatasan dan pembatasan berdasarkan pemanfaatan prinsip straight edge serta do it yourself punk. ${ }^{1}$ Prinsip tersebut merupakan penggabungan dua hal yang bertentangan yang disebut sebagai sinergi oposisi biner, yaitu meletakkan sesuatu yang bertentangan dalam posisi yang sinergis. Sinergi oposisi biner ini terdapat dalam kearifan tradisi nilai-nilai Islam, yaitu koeksistensi khalîfat Allâh fì al-ard-'Abd Allâh, di mana sebagai khalîfat Allâh fì al-ard, manusia merupakan wakil Tuhan di bumi dengan misi menyebarkan

\footnotetext{
1 Dayno Utama, "Upaya Perumusan Prinsip Counter Accounting dengan Memanfaatkan Filosofi Punk Sebagai Counter Culture", Jurnal Akuntansi Multiparadigma, Vol. 6, No. 3 (2015), 444-465.
} 
rahmat bagi alam semesta melalui kreativitasnya, sedangkan 'Abd Allâh merupakan konsep kepatuhan dan ketundukan manusia kepada Tuhan melalui kewajiban manusia untuk mematuhi segala perintah Tuhan dan meninggalkan segala larangan-Nya. Konsep ini telah dimanfaatkan juga dalam membangun Akuntansi Syariah. ${ }^{2}$

Upaya perumusan tersebut membuka peluang untuk dilakukannya upaya islamisasi prinsip counter accounting. Islamisasi tersebut sangat diperlukan karena prinsip counter accounting tersebut dirumuskan dengan memanfaatkan "filosofi punk" yang memiliki reputasi buruk. Penyebabnya adalah banyaknya kasus kekerasan yang melibatkan punk, penyalahgunaan obat terlarang dan kasus kriminal lain. Reputasi buruk punk ini semakin diperparah oleh media massa. Walaupun punk memiliki filosofi perlawanan, pembangkangan dan pemberontakan yang dapat memicu kreativitas tanpa batas, terdapat suatu filosofi punk yang sangat kontradiktif dan radikal dengan karakteristik pembangkangan punk, di mana filosofi ini oleh komunitas punk sendiri sering diabaikan. Filosofi tersebut adalah "bertanggungjawab terhadap segala sesuatu yang dilakukan". Bentuk tindakan bertanggungjawab ini adalah berpikir sebelum berbuat, menghargai orang lain, tidak menilai orang lain hanya dari penampilan luarnya saja dan yang paling penting adalah berkontribusi positif dalam perubahan dunia yang lebih baik. Filosofi tersebut dapat terlihat jelas ketika pada tahun 1981 Minor Threat, sebuah band punk yang berasal dari Washington DC, merilis lagu berjudul straight edge yang menandakan dimulainya sebuah pergerakan di dalam komunitas punk. Pesan yang disampaikan oleh gerakan straight edge ini adalah "Anda tidak harus meminum alkohol, merokok, atau terlibat dalam penggunaan obat terlarang demi untuk bersenang-senang". Straight edge merupakan suatu cara menyelamatkan musik rock dari mitos rock and roll, yaitu membuat musik relevan untuk tiap orang, di mana jika menjalankan gaya hidup rock and roll akan membuat seseorang tidak akan bisa menjalani hidup dengan normal seperti bangun pagi untuk pergi sekolah atau bekerja. ${ }^{3}$ Berdasarkan

${ }^{2}$ Iwan Triyuwono, Akuntansi Syariab: Perspektif, Metodologi, dan Teori (Jakarta: Rajawali Pers, 2012), 339, 342, 357; Aji D. Mulawarman, Menyibak. Akuntansi Syariah: Rekonstruksi Teknologi Akuntansi Syariah dari Wacana ke Aksi (Yogyakarta: Kreasi Wacana, 2006), 66; Aji D. Mulawarman, Akuntansi Syariab: Teori, Konsep, dan Laporan Keuangan (Jakarta: E Publishing Company, 2009), 8.

${ }^{3}$ Lihat Craig O'Hara, The Philosophy of Punk: More Than Noise! (San Francisco: AK Press, 1999); lihat juga, Michael Azerrad, Our Band Could be Your Life: Scenes from the American Underground 1981-1991 (Boston: Little Brown, 2001). 
uraian di atas dapat diketahui bahwa di dalam filosofi punk pun terdapat nilai-nilai Islam sinergi oposisi biner berupa prinsip perlawanan, pembangkangan dan pemberontakan untuk memicu kreativitas yang berdampingan dengan pembatasan dalam bentuk pertanggungjawaban terhadap segala sesuatu yang dilakukan. Dengan islamisasi, maka prinsip counter accounting diharapkan tidak memiliki reputasi buruk karena berperilaku merusak sehingga benar-benar dapat berkontribusi positif untuk perubahan dunia yang lebih baik.

Bagi ilmu agama terutama ilmu agama Islam, islamisasi ilmu pengetahuan sangat diperlukan karena di masa lalu ilmu-ilmu agama pernah digugat eksistensinya akibat adanya klaim bahwa di dalamnya tidak terjadi pengembangan sehingga tidak dapat disebut sebagai ilmu sebagaimana diklaim oleh Harun Nasution. ${ }^{4}$ Hal tersebut dapat dilihat dari ilmu-ilmu agama di perguruan-perguruan Islam yang diklaim tidak berkembang berupa tafsir lama yang diajarkan itu-itu juga, Hadîth sudah tidak bertambah lagi sejak Nabi wafat, demikian pula tauhid yang dibahas dari tahun ke tahun adalah sifat-sifat Allah yang tak bertambah dan tak berkurang, begitu juga fiqh yang dibahas tiap tahun adalah hukum-hukum dari ijtihad ulama masa lampau. Akibatnya pembidangan ilmu agama yang disusun oleh Departemen Agama sempat diragukan Lembaga Ilmu Pengetahuan Indonesia (LIPI) ketika itu. ${ }^{5}$ Hal tersebut terjadi karena salah satu tugas pokok LIPI adalah memberikan saran kepada pemerintah tentang kebijaksanaan nasional di bidang ilmu pengetahuan dan teknologi sesuai dengan peraturan perundang-undangan yang berlaku. ${ }^{6}$ Kepada LIPI dijelaskan bahwa ilmu-ilmu yang diajarkan di IAIN bukan tidak berkembang, tetapi hanya tidak jelas kelihatan, tidak sama halnya dengan ilmu-ilmu umum. Perkembagan ilmu-ilmu agama terlihat jelas dalam mata kuliah Perkembangan Modern di Dunia Islam, karena

${ }^{4}$ Syahrin Harahap, Metodologi Studi dan Penelitian Ilmu-ilmu Ushuludin (Jakarta: PT. RajaGrafindo Persada, 2000), 5.

${ }^{5}$ Ibid., 6.

${ }^{6}$ Pasal 2 Keputusan Presiden Republik Indonesia Nomor 1 Tahun 1986 tentang Lembaga Ilmu Pengetahuan Indonesia, yang mencabut Keputusan Presiden Republik Indonesia Nomor 128 Tahun 1967 tentang Pembentukan Lembaga Ilmu Pengetahuan Indonesia sebagaimana telah beberapa kali diubah terakhir dengan Keputusan Presiden Nomor 43 Tahun 1985. Terakhir hingga saat ini dilakukan penyempurnaan dengan penetapan Keputusan Presiden Republik Indonesia Nomor 103 Tahun 2001 tentang Kedudukan, Tugas, Fungsi, Kewenangan, Susunan Organisasi dan Tata Kerja Lembaga Pemerintah Non Departemen, Pasal 55 hingga 57. 
dalam mata kuliah ini dibahas tafsiran-tafsiran baru yang dihasilkan penafsir-penafsir abad XIX dan XX serta ada pemikiran-pemikiran baru yang ditimbulkan oleh ulama-ulama. Demikian pula ilmu Tauhid. Namun sayangnya perkembangan ini tidak ditonjolkan dalam kurikulum IAIN. Setelah mendengar penjelasan ini, LIPI akhirnya dapat menyetujui pembidangan ilmu yang disusun Departemen Agama dengan catatan supaya mata kuliah Perkembangan Modern di Dunia Islam dijadikan mata kuliah pokok atau wajib pada semua fakultas. Berdasarkan atas persetujuan LIPI ini keluarlah keputusan Menteri Agama No. 1 Tahun 1982 tentang Pembidangan Ilmu Agama Islam. Berdasarkan uraian ini Syahrin Harahap memperlihatkan betapa pentingnya pengembangan ilmu-ilmu agama melalui penelitian, dialog dan perenungan agar klaim seperti disebut di atas tidak terjadi kembali pada ilmu-ilmu agama. ${ }^{7}$ Hal yang sama juga dilakukan dalam penelitian ini dengan fokus pada upaya islamisasi prinsip counter accounting.

Islamisasi prinsip counter accounting dalam penelitian ini dilakukan dengan cara mencari hikmah untuk dapat mengambil pelajaran berdasarkan Q.S. al-Baqarah [2]: 269 berikut:

Allah memberikan hikmah kepada siapa yang dikehendakiNya. Dan barang siapa yang diberi ilmu hikmah, maka sungguh telah diberi kebajikan yang banyak. Dan tidak ada yang dapat mengambil pelajaran melainkan orang-orang yang berakal. ${ }^{8}$

Dalam Tafsîr Ibn Kathîr terdapat berbagai pendapat mengenai apa yang dimaksud dengan "hikmah" dalam ayat ini, salah satunya adalah Ibrâhîm al-Nakhâ̂î yang mengemukakan bahwa "hikmah berarti pemahaman", sedangkan Mâlik mengatakan: "Sesungguhnya terbetik di hatiku bahwa hikmah itu adalah pemahaman tentang agama Allah dan sesuatu yang dimasukkan Allah ke dalam hati yang berasal dari rahmat dan karunia-Nya. Yang dapat memperjelas hal itu adalah bahwa anda mungkin mendapatkan seseorang yang ahli dalam urusan dunianya, jika ia berbicara tentangnya. Dan anda mendapatkan orang lain yang lemah dalam urusan dunianya tetapi ia sangat ahli dan luas pandangannya dalam bidang agama, ini merupakan karunia yang diberikan kepadanya dan dihalangi dari orang pertama." Jadi hikmah

\footnotetext{
${ }^{7}$ Harahap, Metodologi Studi dan Penelitian, 6.

8 Jaka Isgiyarta, Teori Akuntansi dan Laporan Keuangan Islami (Semarang: Badan Penerbit Universitas Diponegoro, 2009), 59.
} 
berarti pemahaman dalam agama Allah. ${ }^{9}$ Penelitian ini menggunakan kedua pendapat ini karena relevan dengan fokus penelitian berupa upaya islamisasi prinsip counter accounting.

Selain itu islamisasi prinsip counter accounting dalam penelitian ini dilakukan berdasarkan kutipan sabda-sabda Nabi Muhammad yang oleh Iwan Triyuwono diyakini dikutip dari karya Nurcholish Madjid: "Pungutlah olehmu hikmah (ilmu pengetahuan atau wisdom) dan tidak akan membahayakan bagi kamu dari bejana apa pun hikmah itu keluar." "Hikmah adalah barang yang hilangnya orang beriman, karena hendaknya ia memungutnya di mana pun ditemukan."10

Berdasarkan kutipan-kutipan di atas diketahui bahwa dalam proses islamisasi ilmu pengetahuan, tidak semua apa yang telah diketahui manusia terutama yang telah diketahui oleh masyarakat Barat bertentangan dengan nilai Islam, karena masih terdapat yang dapat dipertahankan meskipun tentu banyak juga yang bertentangan sehingga harus digantikan oleh nilai yang islami. ${ }^{11}$ Hal ini terlihat dalam beberapa penelitian akuntansi yang telah dilakukan seperti Iwan Triyuwono yang dalam penelitiannya menggunakan Simbolik Interaksionisme diperluas sebagai alat untuk melihat realitas empiris dan memahami maknanya. Diperluasnya Simbolik Interaksionisme ini karena konsep tersebut tidak bebas nilai tetapi terikat dengan nilai-nilai Barat sesuai penggagasnya di mana konsep tersebut berasal, seperti pandangan liberal dan tidak mengakui ketuhanan sementara masyarakat yang akan dipahami adalah masyarakat yang secara sosial dibentuk oleh perspektif Islam secara dominan dengan karakteristik mengakui ketuhanan dan nilai-nilai Islam, sehingga konsep Simbolik Interaksionisme tersebut perlu diperluas atau disesuaikan dengan nilainilai yang melekat dengan konsep dasar Islam yaitu Keimanan Islam, Pengetahuan dan Tindakan agar tidak gagal dalam memahami realitas empiris dan maknanya. ${ }^{12}$ Selain itu terdapat M. Akhyar Adnan yang dalam penelitiannya menggunakan pendekatan kritis dimodifikasi karena penelitiannya tidak sepenuhnya mengadopsi Teori Kritis

\footnotetext{
9 'Abd Allâh b. Muḥammad b. 'Abd al-Raḥmân b. Isḥâq, Tafsîr Ibn Kathîr, Vol. 1, terj. M. Abdul Ghoffar E.M (Bogor: Pustaka Imam Asy-Syafi'i, 2004), 537-538.

10 Triyuwono, Akuntansi Syariah, 64.

11 Sofyan S. Harahap, Kerangka Teori dan Tujuan Akuntansi Syariah (Jakarta: Pustaka Quantum, 2008), 50.

12 Iwan Triyuwono, "Shari'ate Organisation and Accounting: The Reflections of Self's Faith and Knowledge" (Doctor of Philosophy Thesis--Departement of Accounting and Finance, University of Wollongong, 1995).
} 
sebagaimana adanya tetapi menyesuaikannya dengan sudut pandang Islam yaitu nilai-nilai Tauhid. Artikel ini menggunakan Teori Kritis karena dapat digunakan untuk pencerahan dan perubahan emansipasi akan tetapi dalam artikel ini Teori Kritis yang digunakan disesuaikan dengan sudut pandang Islam karena ada yang tidak sesuai seperti emansipasi total tanpa batas. Oleh karena itu penggunaan Teori Kritis dalam artikel ini dibatasi oleh pandangan Islam, yaitu keyakinan bahwa sumber kebenaran hanya berasal dari Allah melalui al-Qur'ân dan Hadîth Nabi sehingga nilai-nilai yang berasal dari keyakinan tersebut tidak perlu dipertanyakan lagi. Berdasarkan sumber ajaran Islam ini, konsep dan praktik akuntansi dalam artikel tersebut akan diinvestigasi. ${ }^{13}$

Islamisasi ilmu pengetahuan dimaksudkan untuk mengembalikan ilmu pengetahuan pada tauhid sehingga pengetahuan melekat dengan iman. Berbagai inisiatif dilakukan untuk mengidentifikasi pengetahuan yang sejalan dengan ajaran Islam $^{14}$ seperti penelitian-penelitian yang telah disebutkan pada uraian sebelumnya dan juga penelitian ini. Islamisasi ilmu pengetahuan menekankan perlunya menggunakan alQur'ân dan alam semesta sebagai sumber untuk membangun ilmu pengetahuan Islam. Penggunaan dua sumber ilmu pengetahuan ini diturunkan dari konsep dasar ilmu pengetahuan Islam, yaitu tauhid. ${ }^{15}$ Ke-Esaan Tuhan (tauhid) adalah prinsip dasar bagi seluruh aspek kehidupan. Konsep tersebut adalah konsep yang memahami Allah sebagai "Penyebab Pertama dan Tertinggi serta Akhir dari segala sesuatu. Keberadaan dan aktivitas-Nya merupakan prinsip dasar dari semua ilmu pengetahuan." Oleh karena itu islamisasi ilmu pengetahuan harus diarahkan pada suatu kondisi analisis dan sintesis tentang hubungan realitas yang sedang dipelajari dengan hukum Tuhan. ${ }^{16}$ Dengan memberikan salah satu contoh pengembangan akuntansi dengan metode sintesis, Iwan Triyuwono mengatakan sintesis sebagai kebalikan dari istilah analisis merupakan sebuah proses berpikir yang berusaha menyatukan bagian-bagian yang

${ }^{13}$ M. Akhyar Adnan, "An Investigation of Accounting Concepts and Practices in Islamic Banks: The Case of Bank Islam Malaysia Berhad and Bank Muamalat Indonesia" (Doctor of Philosophy Thesis--Department of Accounting and Finance, University of Wollongong, 1996).

14 Sony Warsono, Al-Qur'an dan Akuntansi: Menggugah Pikiran Mengetuk Relung Kalbu (Yogyakarta: AB Publisher, 2012), 139.

15 Triyuwono, Akuntansi Syariah, 272.

${ }^{16}$ Ibid., 268. 
terpisah agar diperoleh suatu pemahaman yang atuh. ${ }^{17}$ Dengan demikian keterkaitan antara wahyu dan realitas akan ditemukan yang akan menambah keyakinan atau keimanan keberadaan Tuhan dan kebenaran yang tersebar melalui wahyu-Nya. ${ }^{18}$ Berdasarkan uraian ini maka dapat diketahui bahwa sumber pengetahuan dalam Islam adalah wahyu dan realitas dunia yang pada dasarnya akan menambah keyakinan/keimanan akan keberadaan Tuhan. ${ }^{19}$ Berdasarkan uraian ini pula dapat diketahui bahwa sesungguhnya Islam adalah agama yang lengkap (Q.S. al-An'âm [6]: 38) dan sempurna (Q.S. al-Mâ’idah [5]: 3), sehingga bila seseorang sudah memilih Islam sebagai agamanya, maka kepadanya dituntut sikap totalitas atau menyeluruh (Q.S. al-Baqarah [2]: 208). ${ }^{20}$

Secara utuh hal ini mengandung pengertian bahwa semua tingkah laku hidup manusia yang Islami harus diterapkan pada seluruh bidang kehidupan termasuk akuntansi. ${ }^{21}$ Oleh karena itu al-Qur'ân diyakini mencakup semua fenomena kehidupan dan juga mencakup dasardasar, aturan-aturan serta semua hukum yang berkaitan dengan akidah, ibadah dan muamalah. Hal ini tercermin pada terjemahan firman Allah dalam Q.S. al-Nahl [16]: 89:

“...Dan Kami turunkan kepadamu Al-Kitab (al-Qur'ân) untuk menjelaskan segala sesuatu dan merupakan petunjuk serta rahmat dan kabar gembira bagi orang-orang yang berserah diri".

Islam mengombinasikan antara agama dan dunia, masjid dan negara (ketatanegaraan), materiil dan spirituil, dalam suatu siklus atau jaringan yang seimbang untuk kemaslahatan manusia di dunia dan akhirat. Islam merupakan suatu kesatuan yang tidak dapat dipisahkan sebagaimana tidak boleh mengambil satu bagiannya saja dan meninggalkan bagian yang lain. Jadi kurang tepat jika terdapat pemahaman yang mengatakan bahwa Islam itu hanya agama ibadah terbatas di sekitar masjid dan rumah saja. Kurang tepat pula jika

\footnotetext{
17 Ibid., 371.

${ }^{18}$ Ibid., 306.

${ }^{19}$ Mulawarman, Menyibake Akuntansi Syariah, 81.

${ }^{20}$ M. Akhyar Adnan, Akuntansi Syariah: Arah, Prospek, dan Tantangannya (Yogyakarta: UII Press, 2005), 3.

${ }^{21}$ Muhamad, Prinsip-prinsip Akuntansi dalam Alquran (Yogyakarta: UII Press, 2000), 51.
} 
terdapat pemahaman yang mengatakan bahwa boleh menjalankan sebagian dari Islam dan meninggalkan sebagian yang lain. ${ }^{22}$

Oleh karena itu sebagai kitab suci umat Islam, al-Qur'ân banyak memuat hal-hal (ajaran) yang perlu dipikirkan, digali, ditafsirkan dan dilaksanakan dalam seluruh aspek kehidupan, maka tidak heran apabila terdapat berbagai tulisan yang berusaha menggali ayat-ayat alQur'ân yang terus bermunculan. ${ }^{23}$ Hal tersebut telah banyak dilakukan oleh para ahli akuntansi syariah (akuntansi Islam). Oleh karena itu dalam penelitian ini setelah menemukan hikmah berupa pembelajaran dari argumentasi pembentuk prinsip counter accounting yang sejalan dengan hikmah berupa pembelajaran dari nilai-nilai Islam sebagaimana telah digali oleh para ahli akuntansi syariah (akuntansi Islam) tersebut, maka penelitian ini akan melakukan sintesis terhadap kedua hikmah yang telah ditemukan sehingga diperoleh prinsip counter accounting yang telah diislamisasi. Dengan kata lain, artikel ini memiliki keyakinan bahwa tanda-tanda kekuasaan Allah tersebar dimanapun, bahkan pengetahuan akuntansi juga memperlihatkan tanda-tanda kekuasaan Allah yang hadir untuk menjadi pelajaran bagi manusia berpikir. $^{24}$

\section{Islamisasi Prinsip Kreativitas Tanpa Batas}

Berdasarkan pemahaman terhadap bahan bacaan yang menjadi dasar pembentuk argumentasi prinsip counter accounting, diperoleh "prinsip kreativitas tanpa batas dalam berbagai keterbatasan dan pembatasan" berdasarkan pemanfaatan prinsip straight edge serta do it yourself punk. ${ }^{25}$ Pemahaman terhadap bahan bacaan yang menjadi dasar pembentuk argumentasi prinsip counter accounting tersebut adalah punk yang tidak terkait dengan fashion, cara berpenampilan tertentu, suatu tren anak muda ataupun suatu aliran musik tertentu, tetapi punk dimaksud adalah suatu ide yang memandu dan memotivasi kehidupan. Filosofi punk hadir untuk mendukung dan mewujudkan ide tersebut melalui musik, karya seni, fanzine dan media lain untuk mengekspresikan suatu kreativitas. Untuk mewujudkan ide tersebut maka diperlukan prinsip dasar yaitu "berpikir untuk diri sendiri,

\footnotetext{
22 Husein Syahatah, Pokok-pokok Pikiran Akuntansi Islam, terj. Khusnul Fatarib (Jakarta: Akbar Media Eka Sarana, 2001), 2 \& 13; lihat juga, Muhamad, Prinsip-prinsip Akuntansi, ix.

${ }^{23}$ Muhamad, Prinsip-prinsip Akuntansi, vii.

${ }^{24}$ Warsono, Al-Qur'an dan Akuntansi, 209.

25 Utama, "Upaya Perumusan Prinsip Counter Accounting", 444-465.
} 
menjadi diri sendiri, jangan menyerah dan hanya menerima apa yang telah lazim ada, tapi wujudkan ide dalam kehidupan nyata”. Dengan filosofi tersebut, punk sering dianggap sebagai pembangkang yang hanya ingin terlihat beda dari yang lain. Namun jika punk hanya ingin terlihat beda dari yang lain, maka hal tersebut tidaklah terlalu bermanfaat. Hal yang lebih penting adalah kesadaran untuk menjadi diri sendiri. Karena jika seseorang menyadari siapa dirinya maka ia memiki kebebasan untuk menjadi berbeda dari yang lain karena setiap individu tidak selalu sama dengan yang lain. ${ }^{26}$

Filosofi kreativitas dengan menjadi diri sendiri dari punk tersebut merupakan faktor fundamental agar menjadi kreatif, yaitu berani tampil beda atau tampil dengan identitas sendiri karena tidak suka meniru orang lain. Berdasarkan faktor fundamental ini, dapat diketahui bahwa karakter orang kreatif dicirikan oleh pandangan dan sikapnya yang berlawanan dengan sebagian besar orang lain, tidak menutup berbagai kemungkinan dan selalu bersifat independen, sehingga salah satu kaidah meraih sukses dalam ekonomi kreatif adalah kesuksesan ditentukan oleh kegiatan berpikir anda sendiri, bukan oleh orang lain. ${ }^{27}$

Filosofi punk tersebut memiliki pasangan yang sangat kontradiktif dan radikal dari karakteristik pembangkangan punk, yaitu bertanggungjawab terhadap segala sesuatu yang dilakukan agar punk tidak memiliki reputasi buruk yang disebabkan oleh banyaknya kasus kekerasan yang melibatkan punk, seperti penyalahgunaan obat terlarang dan kasus kriminal lain. Bentuk aktual filosofi ini terlihat pada sebuah pergerakan di dalam komunitas punk, yaitu gerakan straight edge yang menyebarkan pesan bahwa untuk bersenang-senang seseorang tidak harus meminum alkohol, merokok, atau terlibat dalam penggunaan obat terlarang. Para penganut straight edge mengritik drunk punk, yaitu "dengan meminum alkohol, anda berarti memberikan uang anda kepada perusahaan yang membunuh orang, mencemari dunia, menghancurkan banyak keluarga, menyebabkan munculnya pengemudi mabuk, kecanduan alkohol dan bertanggungjawab terhadap munculnya berbagai kejahatan yang ditimbulkan oleh orang yang berada dalam pengaruh alkohol". Bagaimana bisa punk bermanfaat bagi orang lain atau punk bisa mengubah dunia?

\footnotetext{
${ }^{26}$ Lihat O'Hara, The Philosopby of Punk.

27 Suryana, Ekonomi Kreatif: Ekonomi Baru Mengubah Ide dan Menciptakan Peluang (Jakarta: Salemba Empat, 2013), 87, 111, 137, 154.
} 
Selain straight edge, bentuk aktual dari filosofi pembangkang namun bertanggungjawab ini adalah dalam bentuk prinsip punk "do it yourself". Prinsip punk ini merupakan bentuk perlawanan yang mensyaratkan adanya tanggungjawab agar dapat mewujudkan karya yang produktif, kreatif dan menyenangkan. Ide utama dari do it yourself ini adalah tidak bergantung kepada pihak lain dalam berkarya. ${ }^{28}$ Dengan do it yourself ini, band punk tidak membutuhkan perusahaan raksasa untuk mendanai aktivitas mereka atau menilai musik yang mereka mainkan tetapi mereka melihat apa yang dinilai oleh kebanyakan orang sebagai keterbatasan sebagai sesuatu kebaikan ( $a$ virtue what most saw as a limitation), ${ }^{29}$ walaupun sebenarnya bagi punk hampir tidak mungkin mereka mandiri secara keseluruhan karena mereka tetap harus memperhatikan beberapa ketentuan yang berlaku dalam mempertahankan keberadaannya. ${ }^{30}$

Filosofi punk memiliki dua sisi yaitu, penghancuran, pengrusakan, dan anarkis pada satu sisi, kemandirian, kreativitas dan ekspresi opini kritis pada sisi lain, sejalan dengan teori manajemen konflik yang juga memiliki dua sisi bersebrangan, yaitu, jika tidak terdapat konflik akan menimbulkan situasi stagnasi dan tidak berkembang, sedangkan sisi lainnya jika terdapat konflik yang berlebih akan menimbulkan kekacauan dan kerusakan, sehingga filosofi punk tidak hanya berkaitan dengan berpenampilan beda tetapi dapat dimanfaatkan sebagai perangkat inovatif bagi organisasi dan individu karena filosofi punk dapat memicu ide kreatif di luar kebiasaan dan mendorong pemecahan masalah dengan mengubah perspektif. Namun filosofi punk tersebut tetap memerlukan pengendalian agar tidak terjadi kekacauan dan konflik yang tidak terkendali, sehingga diperlukan keseimbangan yang harmonis di antara inisiatif untuk memicu konflik yang akan memecah kebuntuan dan memulai perubahan yang kreatif, tetapi pada saat yang sama diperlukan upaya pencegahan dan perlindungan agar konflik tidak menjadi ekstrem dan malah merusak sistem organisasi secara keseluruhan. ${ }^{31}$ Dengan kata lain, untuk mendorong pengembangan kreativitas dalam organisasi sangat penting suatu budaya yang menyeimbangkan pengendalian dan

\footnotetext{
${ }^{28}$ O'Hara, The Philosophy of Punk.

${ }^{29}$ Azerrad, Our Band Could be Your Life.

30 Alan O'Connor, Punk Record Labels and the Struggle for Autonomy: The Emergence of DIY (Lanham: Lexington Books, 2008).

31 Rainer Zeichhardt, "Management and Punk: Business Outside the Box", Gestalt Theory, Vol. 36, No. 3 (2014), 289-300.
} 
kebebasan bertindak, yaitu jika satu sisi ada pengendalian maka sebaiknya di sisi lain ada kebebasan untuk bertindak, khususnya kebebasan untuk menggali, untuk mengambil risiko atau untuk mengadakan eksperimen tanpa takut gagal atau rugi dengan tidak mengabaikan sistem pengendalian. ${ }^{32}$

Filosofi punk yang memiliki dua sisi berseberangan namun saling melengkapi ini sejalan pula dengan ajaran Islam yang tidak menerima dualisme, tetapi sebaliknya mengakui adanya prinsip "berpasangan" atau saling melengkapi berdasarkan hikmah dari ayat-ayat al-Qur'ân, seperti ayat 36 surah Yâsîn [36] dan ayat 49 surah al-Dhâriyât [51]. ${ }^{33}$ Berdasarkan ayat-ayat tersebut diketahui bahwa segala sesuatu, kecuali Tuhan, diciptakan berpasang-pasangan. ${ }^{34} \mathrm{Hal}$ ini merupakan esensi Islam berupa tauhid atau pengeesaan Tuhan, ${ }^{35}$ di mana Islam mengakui Tuhan sebagai Penguasa alam semesta, maka dengan itu manusia hanya abdi-Nya ('Abd Allâh/konsep kepatuhan dan ketundukan manusia kepada Allah), sementara penguasaan alam semesta hanyalah sebagai wakil Tuhan di bumi (Khalîfat Allâh fî alard). ${ }^{36}$ Dengan demikian manusia diciptakan Allah di muka bumi memiliki fungsi dan peran ganda, yaitu hamba dan fungsi wakil. ${ }^{37}$ Dengan kata lain, tauhid mewujud dalam sinergi oposisi biner bamba dan wakil, 38 atau dapat disebut juga sebagai koeksistensi 'Abd AllahbKhalîfat Allâh fì al-ard. Koeksistensi ini adalah substansi dari nilai-nilai Islam. $^{39}$

Peran manusia sebagai wakil Allah di bumi didasarkan pada ayatayat al-Qur'ân, seperti ayat 30 surah al-Baqarah [2], ayat 39 surah Fâtị [35], ayat 165 surah al-An'âm [6], dan ayat 107 surah al-Anbiyâ' [21].

\footnotetext{
32 Suryana, Ekonomi Kreatif, 147.

33 Triyuwono, Akuntansi Syariah, 275.

34 Mulawarman, Menyibak Akuntansi Syariah, 81. Pembahasan ini sejalan dengan Tafsîr Ibn Kathîr yang menyatakan seluruh makhluk itu berpasang-pasangan; langit dan bumi, siang dan malam, matahari dan bulan, daratan dan lautan, terang dan gelap, iman dan kufur, kematian dan kehidupan, kesengsaraan dan kebahagiaan, surga dan neraka, bahkan sampai pada hewan dan juga tumbuh-tumbuhan, agar manusia mengetahui bahwa Sang Pencipta itu Esa, tiada sekutu bagi-Nya. Lihat Ibn Ishâaq, Tafsîr Ibn Kathîr, Vol. 7, 544.

${ }^{35}$ Mulawarman, Akuntansi Syariah, 103; lihat juga, Mulawarman, Menyibak. Akuntansi Syariah, 70.

36 Mulawarman, Menyibak, Akuntansi Syariah, 241.

${ }^{37}$ Muhammad, Pengantar Akuntansi Syariah (Jakarta: Salemba Empat, 2005), 169.

38 Mulawarman, Menyibak, Akuntansi Syariah, 296.

${ }^{39}$ Ibid., 73; lihat juga Mulawarman, Akuntansi Syariah, 7-8 dan 106.
} 
Berdasarkan ayat-ayat tersebut dapat diketahui bahwa dalam ajaran Islam, manusia sebagai Khalîfat Allâh fî al-ard memiliki misi khusus untuk menyebarkan rahmat bagi alam semesta, ${ }^{40}$ dengan cara menjalankan seluruh aktivitasnya secara kreatif. ${ }^{41}$ Adapun peran manusia sebagai hamba Allah didasarkan pada ayat-ayat al-Qur'ân, seperti ayat 56 surah al-Dhâriyât [51] dan ayat 61 surah Yâsîn [36]. Ayat-ayat tersebut menjelaskan bahwa sebagai hamba Allah manusia harus menunjukkan ketundukan yang berkenaan dengan kewajiban melaksanakan aturan-aturan Allah baik berupa perintah maupun larangan. ${ }^{42}$

Pembahasan koeksistensi 'Abd Allâh-Khalîfat Allâh fî al-ard di atas menegaskan bahwa Islam menolak adanya dikotomi dua hal yang bersifat berlawan, tetapi sebaliknya Islam menerima bahwa dua hal berlawanan atau berbeda yang saling melengkapi. Seperti, jasad tidak dapat meniadakan ruh dan ruh tidak dapat meniadakan jasad. Akal tidak dapat meniadakan kalbu dan kalbu tidak dapat meniadakan akal, karena keduanya adalah pasangan yang saling melengkapi. Hal ini akan selalu ada dalam ajaran Islam. Begitu pula agama dan ilmu pengetahuan juga merupakan unsur-unsur yang saling melengkapi dalam pengembangan ilmu pengetahuan itu sendiri dan pemahaman terhadap agama. ${ }^{43}$ Dengan landasan ini, Iwan Triyuwono telah memanfaatkannya untuk memformulasikan tujuan dasar laporan keuangan akuntansi syariah yang bersifat "materi" adalah untuk pemberian informasi akuntansi, sedangkan yang bersifat "spirit"

\footnotetext{
40 Mulawarman, Akuntansi Syariah Teori, 115. Dalam Tafsîr Ibn Kathîr, ketiga ayat di atas, yaitu Q.S. al-Baqarah [2]: 30, Q.S. Fâțir [35]: 39 dan Q.S. al-An'âm [6]: 165, memiliki substansi pembahasan yang hampir sama, yaitu bahwa Allah telah menjadikan manusia sebagai pemakmur bumi dari generasi ke generasi, dari satu masa ke masa lain, generasi berikutnya setelah generasi sebelumnya. Lihat Ibn Ishâq, Tafsîr Ibn Katbîr, Vol. 3, 344. Sedangkan ayat 107 surah al-Anbiyâ' menjelaskan bahwa Allah telah menjadikan Nabi Muhammad sebagai rahmat bagi semesta alam. Allah mengutusnya sebagai rahmat untuk manusia. Barangsiapa yang menerima rahmat dan mensyukuri nikmat ini, niscaya dia akan berbahagia di dunia dan di akhirat. Sedangkan barangsiapa yang menolak dan menentangnya, niscaya dia akan merugi di dunia dan akhirat. Ibn 'Abbâs berkata: "Barangsiapa yang mengikutinya, niscaya hal itu menjadi rahmat di dunia dan di akhirat. Dan barangsiapa yang tidak mengikutinya, niscaya dia akan ditimpa suatu ujian yang mengenai seluruh umat berupa bencana alam, perubahan bentuk dan fitnah". Ibid., Vol. 5, 490.

${ }^{41}$ Mulawarman, Akuntansi Syariah, 114.

42 Ibid., 109.

${ }^{43}$ Muhammad, Pengantar Akuntansi Syariah, 158.
} 
adalah untuk akuntabilitas. Salah satu dari kedua tujuan ini tidak dapat meniadakan yang lain karena keduanya berada dalam kesatuan sebagaimana bersatunya badan dan ruh manusia. Pemberian informasi seolah-olah merupakan "badan", sedangkan akuntabilitas adalah "ruh". "Badan" tidak akan eksis tanpa "ruh". Demikian juga sebaliknya, "ruh" tidak dapat membumi tanpa "badan". 44

Dalam ajaran Islam selain terdapat dua hal yang berlawanan atau bertentangan yang saling melengkapi sehingga menghasilkan ekuilibrium seperti badan dengan ruh, lahir dengan batin, dunia dengan akhirat, laki-laki dengan perempuan, orang kaya dengan fakirmiskin, terdapat pula pertentangan yang menghasilkan konflik, sehingga harus dipilih salah satu seperti mukmin dengan musyrik, ma'rûf dengan munkar, syukur dengan kufur, surga dengan neraka, halal dengan haram, dan sebagainya. ${ }^{45}$ Pertentangan yang menghasilkan konflik, sehingga harus dipilih salah satu ini terdapat pada prinsip umum akuntansi dalam Islam yang menjadi inti dari surah al-Baqarah ayat 282, yaitu keadilan, kebenaran dan pertanggungjawaban dalam pencatatan. ${ }^{46}$

Sebagai legitimasi utama akuntansi syariah ayat 282 surah alBaqarah $^{47}$ menunjukkan kewajiban bagi umat beriman untuk menulis setiap transaksi yang dilakukan dan masih belum tuntas. Tujuan perintah ayat tersebut adalah untuk menjaga keadilan dan kebenaran. Artinya, perintah tersebut ditekankan pada kepentingan pertanggungjawaban agar pihak-pihak yang terlibat dalam transaksi itu tidak dirugikan sehingga menimbulkan konflik. Oleh karena itu jika terjadi pertentangan antara tujuan informasi akuntansi untuk pengambilan keputusan dengan informasi akuntansi untuk pertanggungjawaban, maka akuntansi dalam Islam lebih menekankan pada pertanggungjawaban ${ }^{48}$ sehingga keragu-raguan dan ketakpastian dapat dihilangkan dari muamalah. ${ }^{49}$ Kata "dengan adil" atau "keadilan" dalam ayat tersebut menurut Departemen Agama diterjemahkan sebagai "dengan benar"; dalam pengertian "keadilan

\footnotetext{
${ }^{44}$ Triyuwono, Akuntansi Syariah, 341-342.

45 Kuntowijoyo, Islam sebagai Ilmu: Epistemologi, Metodologi, dan Etika (Yogyakarta: Tiara Wacana, 2006), 34.

46 Muhamad, Prinsip-prinsip Akuntansi, 42; lihat juga, Sofyan S. Harahap, Akuntansi Islam (Jakarta: Bumi Aksara, 2004), 125.

${ }^{47}$ Mulawarman, Menyibak. Akuntansi Syariah, 253.

${ }^{48}$ Muhamad, Prinsip-prinsip Akuntansi, 6 \& 43.

${ }^{49}$ Warsono, Al-Qur'an dan Akuntansi, 114.
} 
Ilahi". Keadilan dalam arti keyakinan bahwa segala perbuatan manusia kelak akan dinilai oleh Allah. ${ }^{50}$ Selain itu dengan memperhatikan ayat tersebut dapat diketahui bahwa Allah memerintahkan umat Islam untuk menuliskan transaksi baik yang kecil maupun yang besar. Yang perlu juga mendapat perhatian adalah kata "kecil" disebutkan terlebih dahulu diikuti dengan kata "besar". Selain itu Allah mengingatkan pula bahwa setiap kebaikan maupun keburukan sebesar dharrah sekalipun akan mendapat balasan, seperti tercantum dalam ayat 7-8 surah al-Zalzalah [99], sehingga mengajarkan manusia untuk mempedulikan hal-hal yang kecil sekalipun, bukan justru sebaliknya. ${ }^{51}$ Dengan demikian berdasarkan ayat 282 surah al-Baqarah ini dapat diketahui bahwa pencatatan (akuntansi) digunakan sebagai alat untuk bermuamalah seperti utang-piutang dan jual beli. Pencatatan berfungsi untuk menegakkan keadilan dan kebenaran, sebagai bukti dan meminimalkan ketidakjelasan, dan pencatatan berfungsi untuk meningkatkan ketakwaan manusia kepada Allah. ${ }^{52}$

Berdasarkan uraian di atas dapat diperoleh prinsip counter accounting yang telah diislamisasi dengan cara sintesis antara hikmah berupa pemahaman terhadap bahan bacaan yang menjadi dasar pembentuk argumentasi prinsip counter accounting dengan hikmah berupa pembelajaran dari nilai-nilai Islam untuk akuntansi, yaitu "prinsip kreativitas tanpa batas dalam berbagai keterbatasan dan pembatasan" berdasarkan pemanfaatan prinsip straight edge serta do it yourself punk dengan keyakinan bahwa segala perbuatan manusia diketahui dan akan diberikan balasannya oleh Allah. Oleh karena itulah penegakkan nilai-nilai keadilan, kebenaran dan pertanggungjawaban merupakan keniscayaan dalam akuntansi.

\section{Islamisasi Prinsip Dedikasi untuk Pemberdayaan Berdasarkan Pemanfaatan Prinsip Do It Yourself Punk}

Prinsip counter accounting selanjutnya adalah prinsip "dedikasi untuk pemberdayaan melalui pengurangan bahkan penghilangan keterasingan atau keterpinggiran" (a dedication to empowerment via disalienation) berdasarkan pemanfaatan prinsip do it yourself punk. ${ }^{53}$ Prinsip ini dibentuk berdasarkan argumentasi dari prinsip do it yourself

\footnotetext{
50 Triyuwono, Akuntansi Syariah, 188.

51 Warsono, Al-Qur'an dan Akuntansi, 153.

52 Ibid., 189. Substansi pembahasan penelitian ini sejalan dengan pembahasan dalam Tafsîr Ibn Kathîr terkait ayat ini. Lihat Ibn Ishậq, Tafsîr Ibn Kathîr, Vol. 1, 560-569.

${ }^{53}$ Utama, "Upaya Perumusan Prinsip Counter Accounting”, 444-465.
} 
punk yang merupakan prinsip punk untuk pemberdayaan agar keterasingan atau keterpinggiran dapat dikurangi bahkan dihilangkan..$^{54}$ Bentuk pemberdayaan agar keterasingan atau keterpinggiran ini hilang adalah tidak dapat diterimanya keberadaan "rock star" dalam komunitas punk, karena anggota band-band punk tidak jauh berbeda dari para penggemarnya, baik dari penampilan dan maupun dari keahlian bermain musik. Komunitas punk sangat mendorong setiap orang dalam komunitasnya untuk membentuk band sendiri sebagai upaya untuk mendobrak batasan antara superstar dan penggemarnya dengan menyatakan "siapapun bisa menjadi superstar atau tidak ada sama sekali yang bisa". Setiap orang hanya memerlukan keinginan dan alat untuk bermain musik. Pergelaran musik punk sangat berbeda dari konser pada umumnya, di mana pemisahan antara penonton dan musisi yang sedang tampil dihilangkan. Selain itu, band-band punk dengan prinsip do it yourself-nya juga sering saling membantu di antara mereka dalam melakukan tour, membuat rekaman, merilis album dan lain-lain. Selain saling membantu di antara mereka, mereka juga saling meminjamkan alat dan melakukan pembagian uang yang diperoleh secara adil. Hal ini sangat berbeda dari budaya rock and roll, sehingga mereka sangat membenci rock star..$^{55}$

Pemanfaatan prinsip ini untuk akuntansi, terutama untuk penelitian akuntansi, yaitu prinsip dedikasi untuk pemberdayaan yang berdampak pada praktik, sehingga praktisi atau sasaran dari hasil penelitian dapat memperoleh manfaat langsung dari suatu kegiatan penelitian akuntansi. Bentuk penelitian yang sesuai dengan prinsip tersebut adalah penelitian tindakan (action research) dengan mengacu pada kata-kata bijak yaitu "actions speak louder than words" yang secara kongkret dapat diterapkan untuk penelitian akuntansi, yaitu penelitian yang melakukan tindakan nyata (action research) lebih memiliki dampak pemberdayaan dan membawa perubahan yang berarti dari pada penelitian yang hanya menghasilkan teori berupa susunan kata-kata dan/atau rumus-rumus matematika. ${ }^{56}$

Prinsip dalam uraian di atas sejalan dengan ajaran Islam berdasarkan hikmah dari ayat 2-3 surah al-Șaff [61], yaitu: Hai orang-

\footnotetext{
${ }^{54}$ Kevin C. Dunn, "Never Mind the Bollocks: the Punk Rock Politics of Global Communication", Review of International Studies, 34 (2008), 193-210.

55 O'Hara, The Philosophy of Punk.

${ }^{56}$ Utama, "Upaya Perumusan Prinsip Counter Accounting”, 444-465.
} 
orang yang beriman, mengapa kamu mengatakan apa yang tidak kamu kerjakan? Amat besar kebencian di sisi Allah bahwa kamu mengatakan apaapa yang tidak kamu kerjakan. ${ }^{57}$ Melaksanakan sesuatu yang dikatakan berdasarkan ayat ini tampaknya merupakan sesuatu yang agak sulit untuk dilakukan. Hal ini terlihat dari kritik yang diberikan oleh Aji Dedi Mulawarman kepada bank syariah dan lembaga keuangan Islam lainnya, yaitu jika dilihat dari laporan laba rugi yang dibuat, bisa jadi tidak salah kalau memasukkan berbagai bank syariah dan lembaga keuangan Islam lainnya dalam kategori "turunan dari ideologi dan sistem kapitalisme".

Berbagai konsep perekonomian Islam yang banyak dipromosikan sebagai suatu sistem alternatif, pada kenyataanya hanya merupakan salah satu bentuk lain dari sistem perekonomian kapitalistik. Hal itu terlihat dalam praktik akuntansi syariah di mana tidak sedikit pakar akuntansi syariah pragmatis yang pada dasarnya hanya menjustifikasi teori-teori akuntansi konvensional (kapitalistik) dengan berbagai ayatayat al-Qur'ân dan kemudian merangkainya sebagai teori akuntansi syariah tanpa sedikitpun menyentuh landasan filosofisnya. Oleh karena itu, laporan keuangan syariah seharusnya bukan hanya melakukan "foto kopi akuntansi konvensional" dan melakukan "tipex sana-sini" dan kemudian "menempel tulisan yang bernuansa syariah", tetapi laporan keuangan syariah seharusnya memang diturunkan dari nilai-nilai Islam. ${ }^{58}$ Pada kesempatan lain, Mulawarman menyatakan berakuntansi atau berekonomi pada lembaga keuangan Islam saat ini hanya ditempeli simbol syariah atau Islam, padahal nilai yang ada masih bersumber dari nilai-nilai Barat; diperlukan upaya yang bukan hanya melakukan pekerjaan tambal sulam ekonomi Barat menggunakan nilai-nilai Islam. ${ }^{59}$

Kritik yang sama juga diberikan oleh Rania Kamla kepada AAOIFI (Accounting and Auditing Organisation for Islamic Financial Institutions) sebagai badan penyusun standar akuntansi lembaga

\footnotetext{
57 Triyuwono, Akuntansi Syariah, 49. Pembahasan dalam Tafsir Ibn Kathîr terkait ayat QS. al-Shaff [61]: 2-3 ini adalah berupa "Ini merupakan pengingkaran Allah terhadap orang yang menetapkan suatu janji atau mengatakan suatu ucapan tetapi ia tidak memenuhinya. Oleh karena itu, ayat ini dijadikan sebagai landasan bagi ulama Salaf yang berpendapat mengharuskan pemenuhan janji itu secara mutlak, baik janji tersebut adalah sesuatu yang harus dilaksanakan ataupun tidak". Lihat Ibn Ishâqq, Tafsîr Ibn Kathîr, Vol. 8, , 159.

${ }^{58}$ Mulawarman, Menyibak. Akuntansi Syariah, xxv.

${ }^{59}$ Mulawarman, Akuntansi Syariah, xxiv.
} 
keuangan Islam, yaitu meski AAOIFI mengklaim menyusun standar akuntansi berdasarkan syariah, akan tetapi standar yang disusun ternyata tidak berbeda jauh dari standar akuntansi yang telah ada yaitu standar akuntansi kapitalis. Hal ini terlihat dari tujuan laporan keuangan yang ditujukan untuk pengambilan keputusan para investor dalam upaya mereka untuk memaksimalkan laba, di mana hal tersebut tidak menunjukkan perbedaan yang signifikan dengan tujuan laporan keuangan kapitalis, sehingga dapat dikatakan bahwa AAOIFI gagal dalam memberikan standar akuntansi alternatif yang bersumber dari nilai-nilai Islam, sebaliknya AAOIFI malah mendukung dan memperkuat keberadaan ideologi pasar dan kapitalisme. ${ }^{60}$

Kritik kepada AAOFI juga diberikan oleh Mulawarman, yaitu regulasi mengenai bentuk laporan keuangan yang dikeluarkan AAOIFI hanya bentuk laporan keuangan yang tidak berbeda dari akuntansi konvensional. Ketentuan AAOIFI lebih diutamakan untuk kepentingan ekonomi, sedangkan ketentuan syariah, sosial dan lingkungan merupakan ketentuan tambahan. Dampak dari ketentuan AAOFI tersebut adalah membuka peluang perbankan syariah mementingkan aspek ekonomi daripada aspek syariah, sosial maupun lingkungan. Dugaan ini terbukti dari beberapa penelitian empiris yang diyakininya. ${ }^{61}$ Kritik-kritik di atas menunjukkan tidak mudahnya melaksanakan sesuatu yang telah dikatakan, akan tetapi dengan mengingat terjemahan ayat sebelumnya menyadarkan orang beriman bahwa kebencian Allah sangat besar jika tidak melaksanakan sesuatu yang telah dikatakan.

Berdasarkan pembahasan di atas, dapat diperoleh prinsip counter accounting yang telah diislamisasi dengan cara sintesis antara hikmah berupa pembelajaran dari argumentasi pembentuk prinsip counter accounting yang dapat dimanfaatkan untuk penelitian akuntansi berupa action research dengan hikmah berupa pembelajaran dari ayat 2-3 surah al-Ṣaff dan kritik terhadap lembaga keuangan Islam, yaitu berupa prinsip dedikasi untuk pemberdayaan melalui pengurangan bahkan penghilangan keterasingan atau keterpinggiran (a dedication to empowerment via disalienation) berdasarkan pemanfaatan prinsip do it yourself punk dengan keyakinan bahwa kebencian Allah sangat besar jika tidak melaksanakan sesuatu yang telah dikatakan.

${ }^{60}$ Rania Kamla, "Critical Insights into Contemporary Islamic Accounting", Critical Perspectives on Accounting, Vol. 20 (2009), 921-932.

${ }^{61}$ Mulawarman, Akuntansi Syariah, xxviii. 


\section{Islamisasi Prinsip Tidak Menggulingkan tetapi Selalu Menjadi Alternatif Berdasarkan Pemanfaatan}

Prinsip counter accounting yang terakhir adalah prinsip "tidak menggulingkan" atau menggantikan prinsip mainstream yang berlaku umum tetapi tetap selalu menjadi alternatif berdasarkan pemanfaatan prinsip do it yourself punk dan anti-kemapanan (anti-status quo disposition or anti-establishment disposition). ${ }^{6}$ Prinsip ini dibentuk berdasarkan argumentasi dari prinsip do it yourself punk yang membuat mereka memiliki kebebasan dan anti-kemapanan melalui penolakan mereka terhadap kontrak besar dari perusahaan rekaman musik raksasa, karena mereka menolak untuk berkompromi. Mereka menolak bisnis yang memanfaatkan pemberontakan/pembangkangan mereka untuk konsumsi massa (menjadi musik mainstream). Band-band punk menyadari dapat melakukan rekaman sendiri dengan baik. Dengan cara ini maka mereka dapat menetapkan harga sendiri harga jual album, menulis sendiri lirik yang mereka inginkan, memainkan musik yang mereka suka tanpa ada ancaman untuk melakukan kompromi.

Band-band punk menjual album mereka di bawah harga rata-rata dan keuntungan dari penjualan album tersebut malah mereka gunakan untuk membantu band lain dalam melakukan rekaman album. Mereka melakukan seluruhnya secara mandiri, karena yang mereka perlukan hanya uang secukupnya untuk kebutuhan hidup, bukan untuk memperoleh top 40 hits atau pertunjukkan yang dilihat oleh banyak orang. ${ }^{63}$ Band-band yang bergabung dengan perusahaan rekaman musik raksasa berusaha untuk sukses dengan menjadi terkenal dan hidup mewah, sedangkan band undergroud (dalam hal ini band-band punk) berusaha untuk selalu realistis dan memiliki kebanggaan terhadap hal tersebut. Band punk tidak memerlukan anggaran jutaan dolar untuk mempromosikan bandnya atau pertunjukan megah dengan berkali-kali berganti kostum, yang mereka perlukan hanya keyakinan terhadap diri sendiri. Mereka tidak membutuhkan perusahaan raksasa untuk mendanai aktivitas mereka atau menilai musik yang mereka mainkan. Meski mereka tetap independen dan undeground, mereka tetap dapat menjual album mereka sama seperti band yang bekerja sama dengan perusahaan rekaman musik raksasa.

62 Utama, "Upaya Perumusan Prinsip Counter Accounting”, 444-465.

${ }^{63}$ O'Hara, The Philosophy of Punk. 
Mereka membuktikan dengan tetap menjadi independen dan tanpa kompromi, mereka tetap dapat menikmati apresiasi dan kesuksesan. ${ }^{64}$

Prinsip anti kemapanan dan menolak untuk berkompromi dengan perusahaan rekaman musik raksasa dalam uraian di atas sejalan dengan keyakinan dalam Islam mengenai kekayaan berdasarkan hikmah dari ayat-ayat al-Qur'ân, seperti ayat 48 surah al-Najm [53], ${ }^{65}$ ayat 27 surah al-Shûrâ [42], dan ayat 3 surah al-Ṭalâq [65]. ${ }^{66}$ Berdasarkan ayat-ayat tersebut dapat diketahui bahwa Allah memberikan kekayaan yang cukup untuk memenuhi kebutuhan manusia karena Allah menurunkan rejeki dengan ukuran dan ketentuan tertentu. Keyakinan Islam tersebut sejalan dengan prinsip anti-kemapanan punk sebagaimana telah dijelaskan sebelumnya. Pembatasan dalam pengelola kekayaan (sumber daya) agar tidak boros, tidak berlebihan sehingga melewati batas dan tidak pula kikir tetapi pertengahan di antara keduanya ${ }^{67}$ sejalan pula dengan ajaran Islam berdasarkan hikmah dari ayat-ayat al-Qur'ân, seperti ayat 81 dan 127 surah Ṭâhâ [20], ${ }^{68}$ ayat 31 surah al-A'râf [7], ayat 190 surah al-

${ }^{64}$ Azerrad, Our Band Could be Your Life.
${ }^{65}$ Isgiyarta, Teori Akuntansi, 10. Tafsir ayat 48 surah al-Najm ini adalah bahwa Tuhan menyerahkan kepemilikan harta kepada hamba-hamba-Nya dan menjadikan harta itu sebagai hak milik yang sangat berharga bagi mereka. Lihat Ibn Ishạaq, Tafsîr Ibn Kathîr, Vol. 7, 593.

66 Isgiyarta, Teori Akuntansi, 12. Tafsir ayat 27 surah al-Shûrâ ini adalah bahwa seandainya Allah memberikan kepada mereka rejeki di atas kebutuhan mereka, niscaya hal itu akan membawa mereka berlaku sewenang-wenang dan saling menzalimi satu dengan yang lainnya karena angkuh dan sombong. Akan tetapi Dia memberikan rejeki kepada mereka sesuatu yang dipilih-Nya untuk kemaslahatan mereka. Dia mengetahui tentang hal tersebut. Dia menjadikan kaya orang yang berhak menerima kekayaan dan menjadikan fakir kepada orang yang berhak menerima kefakiran. Lihat Ibn Ishâq, Tafsîr Ibn Kathîr, Vol. 7, 253. Sedangkan pembahasan terkait ayat 3 surah al-Ṭalâq ini adalah bahwa barangsiapa bertakwa kepada Allah dalam seluruh perintah-Nya dan menjauhi seluruh larangan-Nya, maka Dia akan membuatkan baginya jalan keluar dan memberinya rejeki dari arah yang tidak diduga, yakni, dari arah yang tidak pernah terbersit dalam hatinya. Dia-lah yang menerapkan seluruh ketetapan dan hukum-Nya yang diberlakukan terhadap semua makhluk-Nya sesuai dengan kehendak dan keinginannya. Ibid., Vol. 8, 212-214.

${ }^{67}$ Isgiyarta, Teori Akuntansi, 14-16, 50-51.

68 Tafsir ayat 81 surah Tâhâ adalah perintah untuk makan dari rejeki yang telah dianugerahkan kepada manusia dan larangan berlebih-lebihan dalam melakukannya, yaitu mengambilnya di luar kebutuhan dan melanggar apa yang telah Allah perintahkan kepada manusia. Lihat Ibn Ishâaq, Tafsîr Ibn Kathîr, Vol. 5, 403. 
Baqarah [2], ${ }^{69}$ ayat 67 surah al-Furqân $[25],{ }^{70}$ dan ayat 26-27 surah alIsrâ' [17].

Berdasarkan uraian di atas diperoleh prinsip counter accounting yang telah diislamisasi dengan cara sintesis antara hikmah berupa pembelajaran dari argumentasi pembentuk prinsip counter accounting dengan hikmah berupa pembelajaran dari nilai-nilai Islam dalam pengelolaan kekayaan, yaitu berupa prinsip tidak menggulingkan atau menggantikan prinsip mainstream yang berlaku umum tetapi tetap selalu menjadi alternatif berdasarkan pemanfaatan prinsip do it yourself punk dan anti-kemapanan dengan keyakinan bahwa Allah memberikan kekayaan dan kecukupan dengan ukuran serta ketentuan tertentu sesuai dengan apa yang dikehendaki-Nya sehingga tidak perlu berlebihan dan melampaui batas.

\section{Penutup}

Hasil penelitian sebagaimana telah dibahas di atas berupa prinsip counter accounting yang telah diislamisasi menunjukkan bahwa tidak semua ilmu pengetahuan dari masyarakat Barat-yang memiliki keyakinan berbeda dari Islam-bertentangan dengan nilai-nilai Islam, karena masih terdapat pengetahuan yang dapat sejalan, meskipun tentu saja terdapat banyak pengetahuan yang bertentangan sehingga harus disintesiskan dengan nilai-nilai Islam. Selain itu hasil penelitian ini juga menunjukkan bahwa ilmu pengetahuan agama Islam dapat terus dikembangkan sehingga klaim yang menyatakan di dalamnya tidak terjadi pengembangan dan tidak dapat disebut sebagai ilmu di masa lalu tidak perlu terjadi kembali. Pada akhirnya, hasil penelitian ini juga menunjukkan tanda-tanda kekuasaan Allah yang akan menambah keyakinan atau keimanan terhadap keberadaan Allah dan kebenaran yang terdapat dalam wahyu-Nya, yaitu al-Qur'ân yang diyakini

${ }^{69}$ Tafsir ayat 190 surah al-Baqarah ini adalah perintah berperang di jalan Allah tetapi tidak berlebih-lebihan dalam melakukannya. Termasuk dalam hal ini adalah melakukan berbagai macam larangan, sebagaimana dikatakan Hasan al-Bishri, seperti menyiksa, menipu, membunuh para wanita, anak-anak dan orang-orang lanjut usia yang sudah lemah pikirannya dan tidak mampu berperang, para pendeta, penghuni rumah ibadah, membakar pepohonan, membunuh hewan tanpa ada maslahat". Ibid., Vol. 1, 365.

70 Pembahasan terkait ayat 67 surah al-Furqân ini adalah supaya manusia tidak terlalu boros dalam mengeluarkan infak, mengaturnya sesuai kebutuhan, tidak membiarkan keluarga mereka, menurunkan hak-hak keluarga mereka, mereka berlalu adil dan baik, dan sebaik-baik perkara adalah pertengahan, tidak boros/lebih dan tidak kikir/kurang. Ibid., Vol. 6, 128-129. 
mencakup semua fenomena kehidupan, sehingga memperkuat keyakinan terhadap Islam sebagai agama yang lengkap dan sempurna. Dengan telah dirumuskannya prinsip counter accounting yang telah diislamisasi dalam artikel ini, maka selanjutnya diperlukan upaya untuk mengaktualisir atau implementasinya. Hal ini karena sebagaimana telah disintesiskan ke dalam salah satu prinsip counter accounting dalam penelitian ini, yaitu keyakinan bahwa kebencian Allah sangat besar jika tidak melaksanakan sesuatu yang telah dikatakan, sehingga diharapkan hal ini tidak terjadi.

\section{Daftar Rujukan}

'Abd Allâh b. Muhammad b. 'Abd al-Raḥmân b. Ishậq, Tafsîr Ibn Kathî, Vol. 3, terj. M. Abdul Ghoffar E.M. Bogor: Pustaka Imam Asy-Syafi'i, 2003.

Adnan, M. Akhyar. "An Investigation of Accounting Concepts and Practices in Islamic Banks: The Case of Bank Islam Malaysia Berhad and Bank Muamalat Indonesia". Doctor of Philosophy Thesis--Department of Accounting and Finance, University of Wollongong, 1996.

----. Akuntansi Syariah: Arah, Prospek, dan Tantangannya. Yogyakarta: UII Press, 2005.

Azerrad, Michael. Our Band Could be Your Life: Scenes from the American Underground 1981-1991. Boston: Little Brown, 2001.

Dunn, Kevin C. "Never Mind the Bollocks: the Punk Rock Politics of Global Communication", Review of International Studies, 34, 2008.

Harahap, Sofyan S. Akuntansi Islam. Jakarta: Bumi Aksara, 2004.

----. Kerangka Teori dan Tujuan Akuntansi Syariah. Jakarta: Pustaka Quantum, 2008.

Harahap, Syahrin. Metodologi Studi dan Penelitian Ilmu-ilmu Ushuludin. Jakarta: PT. RajaGrafindo Persada, 2000.

Isgiyarta, Jaka. Teori Akuntansi dan Laporan Keuangan Islami. Semarang: Badan Penerbit Universitas Diponegoro, 2009.

Isḥ̂aq, 'Abd Allâh b. Muḥammad b. 'Abd al-Raḥmân b. Tafsîr Ibn Kathir, Vol. 1, terj. M. Abdul Ghoffar E.M. Bogor: Pustaka Imam Asy-Syafi'i, 2004.

Kamla, Rania. "Critical Insights into Contemporary Islamic Accounting", Critical Perspectives on Accounting, Vol. 20, 2009.

Kuntowijoyo. Islam sebagai Ilmu: Epistemologi, Metodologi, dan Etika. Yogyakarta: Tiara Wacana, 2006. 
Muhamad. Prinsip-prinsip Akuntansi dalam Alquran. Yogyakarta: UII Press, 2000.

Muhammad. Pengantar Akuntansi Syariah. Jakarta: Salemba Empat, 2005.

Mulawarman, Aji D. Akuntansi Syariah: Teori, Konsep, dan Laporan Keuangan. Jakarta: E Publishing Company, 2009.

Mulawarman, Aji D. Menyibak. Akuntansi Syariab: Rekonstruksi Teknologi Akuntansi Syariah dari Wacana ke Aksi. Yogyakarta: Kreasi Wacana, 2006.

O'Connor, Alan. Punk Record Labels and the Struggle for Autonomy: The Emergence of DIY. Lanham: Lexington Books, 2008.

O'Hara, Craig. The Philosophy of Punk: More Than Noise!. San Francisco: AK Press, 1999.

Suryana. Ekonomi Kreatif: Ekonomi Baru Mengubah Ide dan Menciptakan Peluang. Jakarta: Salemba Empat, 2013.

Syahatah, Husein. Pokok-pokok Pikiran Akuntansi Islam, terj. Khusnul Fatarib. Jakarta: Akbar Media Eka Sarana, 2001.

Triyuwono, Iwan. "Shari'ate Organisation and Accounting: The Reflections of Self's Faith and Knowledge" (Doctor of Philosophy Thesis--Departement of Accounting and Finance, University of Wollongong, 1995.

-----. Akuntansi Syariab: Perspektif, Metodologi, dan Teori. Jakarta: Rajawali Pers, 2012.

Utama, Dayno. "Upaya Perumusan Prinsip Counter Accounting dengan Memanfaatkan Filosofi Punk Sebagai Counter Culture", Jurnal Akuntansi Multiparadigma, Vol. 6, No. 3, 2015.

Warsono, Sony. Al-Qur'an dan Akuntansi: Menggugah Pikiran Mengetuk. Relung Kalbu. Yogyakarta: AB Publisher, 2012.

Zeichhardt, Rainer. "Management and Punk: Business Outside the Box", Gestalt Theory, Vol. 36, No. 3, 2014. 